\title{
HUBUNGAN KEBIASAAN SARAPAN, TINGKAT KECUKUPAN ENERGI, KARBOHIDRAT, PROTEIN DAN LEMAK DENGAN STATUS GIZI PADA SISWA PONDOK PESANTREN AL-FATTAH BUDURAN, SIDOARJO
}

\author{
Relationship between Breakfast Habit, Energy, Carbohydrate, Protein and Fat \\ Adequacy Level with Nutritional Status of Adolescent in Al-Fattah Boarding \\ School Buduran, Sidoarjo \\ Hanik Rosida ${ }^{1}$, Annis Catur Adi ${ }^{2}$ \\ ${ }^{1}$ Program Studi S1 Kesehatan Masyarakat, Fakultas Kesehatan Masyarakat, Universitas Airlangga, Surabaya \\ ${ }^{2}$ Departemen Gizi Kesehatan, Fakultas Kesehatan Masyarakat, Universitas Airlangga, Surabaya \\ Email: hanikrosida22@gmail.com
}

\begin{abstract}
ABSTRAK
Gizi merupakan salah satu faktor yang berperan dalam peningkatan prestasi dan penunjang pertumbuhan bagi remaja. Remaja melakukan banyak aktifitas sehingga membutuhkan asupan gizi yang seimbang. Tujuan penelitian ini adalah untuk mengetahui hubungan antara kebiasaan sarapan dan tingkat kecukupan gizi makro dengan status gizi remaja di Yayasan Pondok Pesantren Al-Fattah, Buduran, Sidoarjo. Penelitian ini merupakan penelitian observasional analitik dengan desain cross sectional. Sebanyak 72 orang siswa SMP dan SMA di Pondok Pesantren Al-Fattah menjadi sampel, pengambilan sampel dengan cara systematic random sampling. Pengumpulan data meliputi kebiasaan sarapan dan konsumsi pangan diukur menggunakan 24 hours food recall dan status gizi berdasarkan Indeks Masa Tubuh menurut umur (IMT/U). Analisis data menggunakan uji regresi logistik. Sebagian besar responden berumur 13-15 tahun (73,6\%) dan berjenis kelamin laki-laki (52,8\%) dan berstatus gizi normal (52,8\%). Terdapat hubungan antara kebiasaan sarapan, tingkat kecukupan karbohidrat dan protein dengan status gizi. Tidak terdapat hubungan antara tingkat kecukupan energi dan lemak dengan status gizi.
\end{abstract}

Kata kunci: kebiasaan sarapan, kecukupan zat gizi makro, status gizi

\begin{abstract}
Nutrition plays vital role in the improvement of academic achievement and growth for adolescent. Adolescent have many activity, therefore needs balance nutritional intake. The aimed of this research was analyzed the relation between breakfast habit, macronutrient adequacy level, with nutritional status of adolescent at Al-Fattah Boarding School, Buduran, Sidoarjo. This research was an analytic observational with cross sectional design. The sample of this research was 72 active students of Al-Fattah Boarding School. Breakfast habit and food consumption were collected through food recall 24 hours. Nutritional status determine by Body Mass Index for Age (BAZ). The logistic regression was used to analyze the data. The results showed that majority of respondent has age 13-15 years (75.6\%), male (52.8\%) and normal nutritional status (52.8\%). There was a relation between breakfast habit, carbohydrate and protein adequacy with nutritional status. There was no relation between energy and fat adequacy with nutritional status.
\end{abstract}

Keywords: breakfast habit, macronutrient adequacy, nutritional status

\section{PENDAHULUAN}

Saat ini Indonesia mengalami masalah gizi ganda, yaitu tingginya prevalensi gizi buruk dan meningkatnya angka obesitas. Remaja umur 13-15 tahun memiliki prevalensi gizi kurang sebesar $11,1 \%$ (3,3\% sangat kurus dan 7,8\% kurus) dan prevalensi gizi lebih sebesar 10,8\% (8,3\% gemuk dan 2,5\% sangat gemuk atau obesitas) (Kemenkes RI, 2013). Remaja umur 16-18 tahun memiliki prevalensi gizi kurang sebesar 9,4\%. Pada tahun 2007 dan 2013 prevalensi remaja gizi kurang relatif sama. Sebaliknya prevalensi gizi lebih pada tahun $2007(1,4 \%)$ naik menjadi 7,3\% pada tahun 2013 (Kemenkes RI, 2013). 
Remaja tengah dengan rentang usia 10-18 tahun rentan mengalami masalah gizi. Kebutuhan akan zat gizi meningkat terkait dengan perubahan gaya hidup (life style), kebiasaan makan dan pada periode ini remaja aktif melakukan olahraga (Almatsier, 2009). Sumber zat gizi seperti karbohidrat, protein, lemak, vitamin, mineral dan air dibutuhkan oleh tubuh dalam sistem metabolisme dalam jumlah dan kualitas yang sesuai. Hal ini juga mempengaruhi status gizi seseorang. Seseorang yang mengonsumsi makanan dalam jumlah dan kualitas yang cukup maka status gizinya akan baik (Irianto, 2010).

Berdasarkan artikel yang dimuat dalam Choirunnisa (2015) menunjukkan program sarapan di sekolah berkaitan erat dengan status gizi remaja sekolah yang normal. Remaja yang melakukan kebiasaan sarapan dengan mengonsumsi makanan tinggi protein seperti telur, dan rendah kalori saat makan siang dapat mengontrol nafsu makan selama 1 hari penuh.

Banyak faktor yang menyebabkan remaja biasa tidak sarapan, salah satunya adalah adanya jadwal pagi yang begitu padat sehingga remaja tersebut merasa tidak memiliki waktu yang cukup dan lupa untuk menyiapkan sarapan. Penyebab lainnya adalah remaja putri menganggap dirinya gemuk sehingga memutuskan untuk tidak sarapan dengan tujuan agar dapat menurunkan berat badan (International Food Information Council Foundation, 2008). Berdasarkan penelitian yang dilakukan oleh Adesola, dkk. (2014), mayoritas remaja yang melewatkan waktu sarapan merefleksikan ketidakcukupan uang makan, jadwal yang padat dan mengontrol berat badan.

Makan pagi sangat penting guna menjaga status gizi dan kesegaran jasmani. Perhitungan zat gizi yang terkandung dalam makanan yang dikonsumsi dapat mencerminkan status gizi seseorang. Kekurangan gizi pada masa remaja akan berdampak pada aktifitas siswa di sekolah seperti lesu, mudah letih, lelah, terhambatnya pertumbuhan, kurang gizi pada masa dewasa dan menurunnya belajar di sekolah (Almatsier, 2009).

Institusi pendidikan dengan dasar keagamaan yang tumbuh dan berkembang di masyarakat salah satunya adalah pondok pesantren. Institusi ini berperan penting dalam pengembangan sumber daya manusia di Indonesia. Kegiatan siswa di pondok pesantren cukup padat dan berdampak terhadap pengeluaran energi dan perilaku konsumsi yang tidak teratur pada santri. Santri pondok pesantren memiliki aktifitas lebih padat dan kebiasaan yang khas dibandingkan dengan siswa sekolah pada umumnya.

Beberapa kebiasaan yang sering dilakukan oleh seorang santri pondok pesantren yaitu mereka sering berpuasa sunnah, sholat malam, dzikir pagi dan petang, dan hidup dalam kesederhanaan sehingga berpengaruh pada pola makan. Pola makan ini mempengaruhi jumlah asupan yang masuk ke dalam tubuh. Di sisi lain, santri juga harus menjalankan sistem yang ada di dalam pondok pesantren sehingga kepadatan aktifitas ini membuat para santri kerap melupakan pemenuhan hak terhadap penjagaan kesehatan tubuhnya. Hal ini mempengaruhi kebiasaan yang dilakukan sehari-hari seperti tidak menyempatkan diri untuk sarapan, pola makan tidak teratur, dan jarang berolahraga.

Yayasan Pondok Pesantren Al-Fatah berlokasi di Desa Banjarsari, Kecamatan Buduran, Kabupaten Sidoarjo. Pondok tersebut masih tergolong tradisional. Para santri putri dan putra tinggal dalam pondok terpisah. Setiap pondok putri dan putra juga terdapat pelayanan makanannya seperti dapur rumah tangga pada umumnya. Berdasarkan uraian tersebut maka penulis ingin mengetahui hubungan status gizi dengan kebiasaan sarapan dan kecukupan gizi pada siswa remaja di Yayasan Pondok Pesantren Al-Fattah Buduran, Kabupaten Sidoarjo.

\section{METODE}

Penelitian ini adalah penelitian observasional dengan desain penelitian cross-sectional. Penelitian ini dilakukan di Yayasan Pondok Pesantren Al-Fattah Desa Banjarsari, Kecamatan Buduran, Kabupaten Sidoarjo. Waktu penelitian mulai dilaksanakan pada bulan Juli 2016-Januari 2017, sedangkan waktu pengambilan data dilakukan pada bulan Desember 2016.

Sampel yang dipilih sebagai subyek adalah remaja putra dan putri yang merupakan siswasiswi kelas VII-VIII SMP dan X-XI SMA berusia 
13-18 tahun dan bersedia menjadi responden. Penentuan sampel dilakukan dengan menentukan jumlah minimum sampel menggunakan rumus $\mathrm{n}=\mathrm{N} /\left(1+\mathrm{N} . \mathrm{d}^{*} 2\right)$ (Notoatmojo, 2010). Sampel dalam studi ini sebanyak 72 santri dan cara pengambilan sampel menggunakan systematic random sampling (Santjaka, 2011).

Variabel dalam penelitian ini adalah status gizi diukur dengan menghitung indeks massa tubuh menurut umur (IMT/U) dengan begitu dapat membedakan yang normal dan tidak normal. Data kebiasaan sarapan diperoleh dengan menggunakan kuesioner sehingga dapat diketahui memiliki kebiasaan sarapan atau tidak sarapan. Data tingkat kecukupan gizi meliputi energi, karbohidrat, protein dan lemak didapat dengan wawancara 24 hours food recall sehingga dapat melihat cukup atau tidaknya zat gizi yang dikonsumsi menggunakan aplikasi nutrisurvey.

Data dianalisis dengan menggunakan uji statistik regresi logistik untuk mengetahui hubungan dan besar risiko kejadian kebiasaan sarapan dan tingkat kecukupan gizi makro dengan status gizi remaja. Penelitian ini sudah mendapatkan sertifikat etik No. 642-KEPK dari Fakultas Kesehatan Masyarakat Universitas Airlangga.

\section{HASIL DAN PEMBAHASAN}

\section{Status Gizi}

Sebagian besar responden pada kelompok umur $13-15$ tahun $(73,6 \%)$ dan berjenis kelamin laki-laki (52,8\%). Tabel 1 menunjukkan sebagian besar responden berstatus gizi normal $(52,8 \%)$.
Tabel 1. Distribusi Responden Berdasarkan Status Gizi

\begin{tabular}{lcc}
\hline \multirow{2}{*}{ Status Gizi } & \multicolumn{2}{c}{ Total } \\
\cline { 2 - 3 } & $\mathbf{n}$ & $\mathbf{\%}$ \\
\hline Kurang & 11 & 15,2 \\
Normal & 38 & 52,8 \\
Gemuk & 23 & 32,0 \\
Total & 72 & 100,0 \\
\hline
\end{tabular}

\section{Kebiasaan Sarapan}

Kebiasaan sarapan dikategorikan menjadi biasa sarapan bila melakukan sarapan $\geq 4$ kali seminggu dan tidak biasa sarapan bila melakukan sarapan $<4$ kali seminggu.

Pada tabel 2 diketahui bahwa sebagian besar responden $(54,2 \%)$ tidak biasa sarapan. Terdapat banyak faktor penyebab responden tidak sarapan, sebagian besar responden menyatakan tidak sarapan karena tidak sempat atau tidak ada waktu untuk sarapan.

International Food Information Council Foundation (2008) menjelaskan bahwa faktor yang menyebabkan remaja tidak sarapan, adalah adanya jadwal pagi yang begitu padat sehingga remaja tersebut merasa tidak memiliki waktu yang cukup untuk menyiapkan sarapan serta kekurangan dana. Selain itu remaja lupa untuk mengonsumsi sarapannya akibat dari adanya jadwal pagi yang cukup padat, serta karena remaja tersebut menganggap dirinya gemuk sehingga memutuskan untuk tidak sarapan dengan tujuan agar dapat menurunkan berat badan.

Tabel 3 menunjukkan bahwa sebagian besar $(98,6 \%)$ responden sering mengonsumsi makanan berat saat sarapan. Pola makan saat sarapan yang

Tabel 2. Distribusi Kebiasaan Sarapan Responden

\begin{tabular}{llrr}
\hline \multicolumn{1}{c}{ Kebiasaan Sarapan } & \multicolumn{1}{c}{ Alasan } & n & \% \\
\hline Biasa Sarapan $(\mathrm{n}=33)$ & Butuh Energi & 33 & 45,8 \\
Tidak Biasa Sarapan $(\mathrm{n}=39)$ & Bangun Kesiangan & 2 & 2,8 \\
& Tidak Merasa Lapar & 3 & 4,2 \\
& Tidak Sempat/ Tidak Ada Waktu & 19 & 26,4 \\
& Tidak Suka Dengan Makanannya & 15 & 20,8 \\
\hline
\end{tabular}


Tabel 3. Distribusi Jenis Makanan yang Sering Dikonsumsi Saat Sarapan

\begin{tabular}{|c|c|c|}
\hline Jenis Sarapan & n & $\%$ \\
\hline Makanan pokok + Lauk & 46 & 63,9 \\
\hline Makanan pokok + Lauk + Sayur & 22 & 30,5 \\
\hline Makanan pokok + Lauk + Sayur/mie + Telur & 1 & 1,4 \\
\hline Mie + Sosis & 1 & 1,4 \\
\hline Roti + Susu & 1 & 1,4 \\
\hline Hanya Minuman & 1 & 1,4 \\
\hline Total & 72 & 100,0 \\
\hline
\end{tabular}

biasa dikonsumsi responden adalah makanan pokok dan lauk.

Hasil penelitian ini menemukan bahwa sebagian besar responden, sarapan dengan kualitas diet yang kurang baik. Responden mengonsumsi makanan sumber karbohidrat dan protein nabati seperti nasi dan tahu tempe tanpa sayur maupun buah-buahan yang dapat mengakibatkan rendahnya asupan serat saat sarapan. Sarapan yang baik seharusnya mengandung energi $20-25 \%$ atau $1 / 5$ dari kebutuhan energi total sehari.

Responden yang biasa sarapan sebagian besar $(84,8 \%)$ berstatus gizi normal. Terdapat hubungan yang signifikan $(\mathrm{p}<0,05)$ antara kebiasaan sarapan dengan status gizi pada siswa Pondok Pesantren Al-Fattah Buduran, Sidoarjo. Kemungkinan remaja yang tidak biasa sarapan akan memiliki status gizi tidak normal 17 kali lebih besar jika dibandingkan dengan remaja yang biasa sarapan.

Berdasarkan penelitian yang dilakukan oleh Garg, dkk (2014) remaja usia 10-16 tahun yang melewatkan sarapan mempunyai konsumsi sereal, susu, sayuran dan buah dan makanan berlemak yang rendah. Penelitian lain menunjukkan bahwa remaja yang melewatkan waktu sarapan mempunyai perbedaan asupan energi dibandingkan dengan remaja yang tidak melewatkan waktu sarapan (Adesola, dkk., 2014).

Orang yang tidak biasa sarapan lebih mungkin untuk mengonsumsi camilan yang tinggi lemak dan memiliki kadar kolesterol yang lebih tinggi dibandingkan orang yang sarapan. Hal ini dapat memicu terjadinya obesitas (Shaw, 1998). Penelitian yang dilakukan oleh Garg, dkk. (2014) menemukan sebanyak $23,5 \%$ remaja sekolah usia 10-16 tahun melewatkan sarapan. Remaja yang melewatkan waktu sarapan lebih banyak mengalami overweight dibandingkan remaja yang tidak melewatkannya. Hasil penelitian yang dilakukan oleh Adesola, dkk. (2014) memperlihatkan hasil yang sama yakni hampir separuh remaja usia 16-20 tahun melewatkan waktu sarapan.

Hal ini sejalan dengan penelitian McCormick, et al. (2010) yakni terdapat hubungan antara konsumsi sarapan dengan penurunan risiko overweight dan obesitas. Sarapan pagi secara teratur dapat menurunkan angka risiko terjadi overweight.

\section{Tingkat Kecukupan Energi}

Tidak ada hubungan antara kecukupan energi dengan status gizi pada siswa Pondok Pesantren Al-Fattah Buduran, Sidoarjo $(\mathrm{p}>0,05)$. Dikemukakan pula oleh Ade dan Mahmudiono (2013) bahwa asupan energi tidak berhubungan dengan status gizi. Aktifitas fisik merupakan salah satu penyebab yang dapat mempengaruhi status gizi seseorang. Seseorang dengan tingkat kecukupan energi kurang namun didukung dengan aktifitas fisik ringan maka akan meningkatkan risiko terjadinya gizi lebih.

\section{Tingkat Kecukupan Karbohidrat}

Sebagian besar responden $(84,2 \%)$ dengan tingkat kecukupan cukup memiliki status karbohidrat gizi yang normal. Ada hubungan yang signifikan antara kecukupan karbohidrat dengan status gizi pada siswa Pondok Pesantren Al-Fattah Buduran, Sidoarjo $(\mathrm{p}<0,05)$. Kemungkinan remaja dengan kebutuhan karbohidrat yang tidak cukup akan berstatus gizi tidak normal 8 kali lebih besar jika dibandingkan dengan remaja yang kebutuhan karbohidrat cukup. 
Tabel 4. Tabulasi Silang Kebiasaan Sarapan dan Tingkat Kecukupan Gizi dengan Status Gizi

\begin{tabular}{|c|c|c|c|c|c|c|c|c|}
\hline \multirow{3}{*}{ Kebiasaan Sarapan } & \multicolumn{4}{|c|}{ Status Gizi } & \multirow{2}{*}{\multicolumn{2}{|c|}{ Total }} & \multirow{3}{*}{ p value } & \multirow{3}{*}{$\operatorname{Exp}(B)$} \\
\hline & \multicolumn{2}{|c|}{ Normal } & \multicolumn{2}{|c|}{ Tidak Normal } & & & & \\
\hline & $\mathbf{n}$ & $\%$ & $\mathbf{n}$ & $\%$ & n & $\%$ & & \\
\hline \multicolumn{9}{|l|}{ Kebiasaan Sarapan } \\
\hline Biasa Sarapan & 28 & 84,8 & 5 & 15,2 & 33 & 100 & & \\
\hline Tidak Biasa Sarapan & 10 & 25,6 & 29 & 74,4 & 39 & 100 & 0,005 & 17,471 \\
\hline Total & 38 & 52,8 & 34 & 47,2 & 72 & 100 & & \\
\hline \multicolumn{9}{|l|}{ Tingkat Kecukupan Energi } \\
\hline Cukup & 18 & 78,3 & 5 & 21,7 & 23 & 100 & & \\
\hline Tidak Cukup & 20 & 40,9 & 29 & 59,2 & 49 & 100 & 0,790 & 1,344 \\
\hline Total & 38 & 52,8 & 34 & 47,2 & 72 & 100 & & \\
\hline \multicolumn{9}{|c|}{ Tingkat Kecukupan Karbohidrat } \\
\hline Cukup & 32 & 84,2 & 6 & 15,8 & 38 & 100 & & \\
\hline Tidak Cukup & 6 & 17,6 & 28 & 82,4 & 34 & 100 & 0,029 & 8,651 \\
\hline Total & 38 & 52,8 & 34 & 47,2 & 72 & 100 & & \\
\hline \multicolumn{9}{|l|}{ Tingkat Kecukupan Protein } \\
\hline Cukup & 32 & 82,1 & 7 & 17,9 & 39 & 100 & & \\
\hline Tidak Cukup & 6 & 18,2 & 27 & 81,8 & 33 & 100 & 0,024 & 8,651 \\
\hline Total & 38 & 52,8 & 34 & 47,2 & 72 & 100 & & \\
\hline \multicolumn{9}{|l|}{ Tingkat Kecukupan Lemak } \\
\hline Cukup & 22 & 68,7 & 10 & 31,3 & 32 & 100 & & \\
\hline Tidak Cukup & 16 & 40 & 24 & 60 & 40 & 100 & 0,322 & 0,407 \\
\hline Total & 38 & 52,8 & 34 & 47,2 & 72 & 100 & & \\
\hline
\end{tabular}

Berdasarkan recall 24 jam, sumber karbohidrat yang dikonsumsi oleh responden sudah bervariasi, antara lain; nasi, mie, terigu, biskuit dan roti serta jagung dan singkong. Karbohidrat merupakan zat gizi sumber energi utama dan merupakan bahan makanan yang harganya relatif lebih murah dibanding dengan zat gizi lain (Almatsier, 2009). Penelitian Adesola, dkk. (2014) menunjukkan bahwa remaja yang melewatkan waktu sarapan mempunyai perbedaan rata-rata asupan karbohidrat dengan remaja yang tidak melewatkan waktu sarapan.

Karbohidrat merupakan penyumbang energi terbesar dalam tubuh (Sediaoetama, 2010). Makanan sumber karbohidrat yang paling sering dikonsumsi oleh responden adalah nasi. Menurut Paath dkk (2004) masyarakat Indonesia mengonsumsi nasi sebagai sumber karbohidrat. Konsumsi karbohidrat berlebih akan disimpan dalam bentuk glikogen dalam jaringan otot dan juga dalam bentuk lemak yang akan disimpan dalam jaringan-jaringan adiposa seperti perut, bagian bawah kulit.

\section{Tingkat Kecukupan Protein}

Sebagian besar responden $(82,1 \%)$ dengan tingkat kecukupan protein yang baik mempunyai status gizi normal. Terdapat hubungan yang signifikan $(p<0,05)$ antara kecukupan protein dengan status gizi pada siswa Pondok Pesantren Al-Fattah, Buduran, Sidoarjo. Kemungkinan remaja dengan tingkat kecukupan protein yang tidak cukup akan berstatus gizi tidak normal 21 kali lebih besar jika dibandingkan dengan remaja yang tingkat kecukupan protein yang baik.

Berdasarkan hasil penelitian yang dilakukan oleh Adesola, dkk. (2014), remaja yang melewatkan waktu sarapan memiliki perbedaan yang signifikan antara rata-rata asupan protein dan lemak dengan remaja yang tidak melewatkan waktu sarapan. Penelitian yang dilakukan oleh Ogechi (2007) menunjukkan bahwa konsumsi sumber protein 
menyumbang $9 \%$ dari kebutuhan protein yang dibutuhkan tubuh. Penelitian tersebut menyebutkan bahwa remaja putri di Nigeria mengalami penurunan konsumsi protein yang diakibatkan oleh bahan makanan sumber protein masih tergolong mahal di negara tersebut. Kekurangan protein pada remaja di Umuahia tersebut berefek pada status gizinya. Hal ini menjadi catatan penting bagi rumah tangga dan sekolah yang berasrama untuk mengatur menu makanan bersumber dari protein bagi anak-anaknya.

\section{Tingkat Kecukupan Lemak}

Sebagian besar responden (68,7\%) dengan tingkat kecukupan lemak yang cukup mempunyai status gizi normal. Tidak ada hubungan yang signifikan antara tingkat kecukupan lemak dengan status gizi pada siswa Pondok Pesantren Al-Fattah, Buduran, Sidoarjo. Berdasarkan penelitian Garg dkk. (2014) diketahui remaja yang melewatkan waktu sarapan mempunyai konsumsi makanan berlemak (saturated fat) yang lebih tinggi dibandingkan dengan remaja yang tidak melewatkan waktu makan. Penelitian lain menyebutkan bahwa asupan rata-rata lemak pada remaja yang melewatkan waktu sarapan mempunyai perbedaan yang signifikan dengan remaja yang melakukan sarapan (Adesola, dkk., 2014).

Hal ini didukung dengan penelitian yang dilakukan oleh Hanifah dan Nindya (2013) yaitu tidak adanya hubungan tingkat kecukupan (karbohidrat dan lemak) dengan status gizi responden. Menurut Barasi (2007), lemak 20-25\% dari energi total diperlukan untuk menjalankan fungsi tubuh dengan baik.

\section{KESIMPULAN DAN SARAN}

Terdapat hubungan antara kebiasaan sarapan, tingkat kecukupan karbohidrat dan protein dengan status gizi siswa Pondok Pesantren Al-Fattah, sedangkan untuk tingkat kecukupan energi dan lemak tidak terdapat hubungan dengan status gizi pada siswa Pondok Pesantren Al-Fattah.

Disarankan pada institusi pendidikan dengan program asrama lebih memperhatikan asupan makan sarapan dengan pola makan seimbang dengan adanya makanan pokok seperti nasi, lauk nabati dan hewani, dan juga sayur, dan melakukan cek berat badan dan tinggi badan secara rutin 3 bulan sekali atau 6 bulan sekali untuk memantau status gizi siswa remaja.

\section{DAFTAR PUSTAKA}

Ade, C.N.D., \& Mahmudiono, T. (2013). Hubungan pola makan, aktifitas fisik, sikap, dan pengetahuan tentang obesitas dengan status gizi pegawai negeri sipil di kantor Dinas Kesehatan Provinsi Jawa Timur. Jurnal Media Gizi Indonesia, 9(1), 42-48. Diakses dari http://journal.unair.ac.id/ filerPDF/mgi512ac5572ffull.pdf.

Adesola, O.A., Ayodeji R.M., Akorede Q.J., \& Olurati O. (2014). Breakfast habit and nutritional status of undergraduates in Ekiti State, Nigeria. Science Journal Of Public Health, 2(4), 252-256. Diakses dari http://www. sciencepublishinggroup.com/j/sjph.

Almatsier, S. (2009). Prinsip dasar ilmu gizi. Jakarta: PT. Gramedia Pustaka Utama.

Barasi, M.E. (2007). At a glance ilmu gizi. Jakarta: Erlangga.

Choirunnisa, B. (2015). Hubungan lingkar pinggang dengan melewatkan sarapan pada remaja putri (Skripsi tidak dipublikasikan). Universitas Brawijaya, Malang.

Garg, M., Rajesh V., \& Kumar P. (2014). Effect of breakfast skipping on nutritional status and school performance of 10-16 years old children of Udupi district. Health and Population Perspective and Issue, 37(3 tim.

Hanifah, N., \& Nindya, S.N. (2013). Hubungan kontribusi beban glikemik makanan dan aktifitas fisik terhadap kejadian gizi lebih pada remaja di SMP full day Surabaya. Jurnal Media Gizi Indonesia, 9(1), 66-71.

International Food Information Council Foundation. (2008). Breakfast and health. Diakses dari http://www.foodinsight.org/Content/6/IFIC\%20 Brkfast \%20Review\%20FINAL.pdf.

Irianto, K. (2010). Gizi dan pola hidup sehat. Yrama Widya: Bandung.

Kementrian Kesehatan RI. (2013). Riset Kesehatan Dasar 2013. Jakarta: Badan Penelitian Dan Pengembangan Kesehatan.

McCormick, T., Thomas J.J., Bainivualiku A., Khan A.N., \& Becker A.E. (2010). Breakfast skipping as a risk correlate of overweight and obesity in school-going ethnic Fijian adolescent girls. 
Asia Pacific journal of clinical nutrition, 19(3), 372-382. Diakses dari http://www.ncbi.nlm.nih. gov/pubmed/20805082.

Notoatmodjo, S. (2010). Metode penelitian kesehatan. Jakarta: Rineka Cipta.

Ogechi, U.P., Akhakhia O.I., \& Ugwunna U.A. (2007). Nutritional status and energy intake of adolescents in Umuahia Urban, Nigeria. Asian Network for Scientific Information.Pakistan Journal of Nutrition 6(6), 641-646. Diakses dari http://agris.fao.org/agris-search/search. do? recordID=DJ2012053495.
Paath, Francin E., Rumdasih Y., Heryati. (2004). Gizi dalam kesehatan reproduksi. Jakarta: ECG.

Santjaka, A. (2011). Statistik untuk penelitian kesehatan (deskriptif, inferensial, parametrik dan non parametrik. Yogyakarta: Nuha Medika.

Sediaoetama, A. (2010). Ilmu gizi. Jakarta: Dian Rakyat.

Shaw, M.E. (1998). Adolescent breakfast skipping: an Australian study. Adolescence, Winter 1998, 33(132), 851-861. Diakses dari https://www. ncbi.nlm.nih.gov/pubmed/9886013. 